\title{
Poemas
}

\author{
Antonio Deltoro
}

\section{A Un Vaso}

Querido vaso

que me esperas

predestinado

a la cerveza

$y$ al agua:

cercano

al manantial, vigoroso, honesto como el martillo, tan a la mano de la mano, tan adaptado a la palma y los dedos. 
No te empolvarás en la costumbre; no dejará de ser un privilegio

llevarte, lejos del charco a los labios, libre de tierra,

querido vaso que me esperas, transparente, cóncavo y limpio, hospitalario y cilíndrico, en la confianza de la mesa. 